\title{
Corrigendum: Triage Approaches Send Adverse Political Signals for Conservation
}

\author{
Ralf C. Buckley* \\ School of Environment, Griffith University, Gold Coast, QLD, Australia
}

Keywords: conservation policy, corporation, landscape, rights, trade-off, economic

\section{OPEN ACCESS}

Edited and reviewed by:

Matt W. Hayward,

Bangor University, UK

${ }^{*}$ Correspondence:

Ralf C. Buckley

r.buckley@griffith.edu.au;

ralf.c.buckley@gmail.com

Specialty section:

This article was submitted to

Conservation,

a section of the journal

Frontiers in Ecology and Evolution

Received: 26 April 2016

Accepted: 08 June 2016

Published: 28 June 2016

Citation:

Buckley RC (2016) Corrigendum: Triage Approaches Send Adverse Political Signals for Conservation.

Front. Ecol. Evol. 4:76.

doi: 10.3389/fevo.2016.00076

\section{A corrigendum on}

Triage Approaches Send Adverse Political Signals for Conservation

by Buckley, R. C. (2016). Front. Ecol. Evol. 4:39. doi: 10.3389/fevo.2016.00039

Reason for Corrigendum:

Owing to an oversight, there was a mistake in the section "Triage of Populations," last sentence of the last paragraph. The phrase “... a viable wild breeding population...” should read "... no viable wild breeding population...". This correction does not change the scientific conclusions of the article.

\section{AUTHOR CONTRIBUTIONS}

The author confirms being the sole contributor of this work and approved it for publication.

Conflict of Interest Statement: The author declares that the research was conducted in the absence of any commercial or financial relationships that could be construed as a potential conflict of interest.

Copyright $(\odot 2016$ Buckley. This is an open-access article distributed under the terms of the Creative Commons Attribution License (CC BY). The use, distribution or reproduction in other forums is permitted, provided the original author(s) or licensor are credited and that the original publication in this journal is cited, in accordance with accepted academic practice. No use, distribution or reproduction is permitted which does not comply with these terms. 